\title{
Susceptibility variation to different entomopathogenic nematodes in Strategus aloeus L (Coleoptera: Scarabaeidae)
}

\author{
A. Gómez and A. Sáenz-Aponte* (i)
}

\begin{abstract}
Strategus aloeus L (Coleoptera: Scarabaeidae), known as "Little bull" or oil palm "chiza" is a limiting pest in palm plantation in Cesar Colombia. Its management is based on pesticide use or old palm removal in renewal lots. Therefore, other alternatives are being sought out. Entomopathogenic nematodes isolated from the Colombian Andean region were evaluated. Under laboratory conditions S. aloeus third instar larvae exposure to 160 infective juveniles (IJs) per/cm² Steinernema sp3 JCL027, S. feltiae SCT125, S. websteri JCL006, S. colombiense SNI0198, Heterorhabditis bacteriophora HNI0100, H. bacteriophora HASA702, H. indica SL0708 ( $n=20)$ was evaluated under a completely randomized design. The experiment was repeated three times on different dates. Significant differences were observed $(F=11.127, d f=7.24, p=0.0054)$, registering mortality between 3 and 14 days. Steinernema sp3 JCL027 was the strain producing the highest mortality rate (19.3 $\pm 8 \%)$, followed by H. bacteriophora HNIO100 (5.2 $\pm 9 \%)$. Thus, we evaluated Steinernema sp3 JCL0270 using a randomized design at 0, 160, 290, 420, 550, 680, $810 \mathrm{IJs} / \mathrm{cm}^{2}(\mathrm{n}=12)$. The experiment was repeated three times on different dates. Significant differences were found among treatments $(44 \pm 5 \%, F=14.676 ; \mathrm{df}=6.21, \mathrm{p}=0.001)$, with $680 \mathrm{IJs} / \mathrm{cm}^{2}$ producing the highest mortality followed by $810 \mathrm{lJs} /$ $\mathrm{cm}^{2}(22 \pm 5 \%)$. In conclusion, this alternative must be further explored in search of pesticide use and cost reduction, in addition to young palm loss in a plantation.
\end{abstract}

Keywords: Little bull, Chiza, Oil palm, Steinernematidae, Heterorhabditidae, Larvae, Biological control

\section{Background}

Strategus aloeus L (Coleoptera: Melolonthidae), known as "Little bull" or "chiza" is an oil palm insect pest in Colombia, Venezuela, Guyana, Suriname, Northern Brazil, Ecuador, and Peru (Aldana et al. 2005). In Colombia, Meta and Cesar are the two departments with greatest national palm industry participation (Torres-Carrasco et al. 2013). Oil palm damage is caused generally by the adult male drilling a hole in the ground, with variable length up to $1.5 \mathrm{~m}$, around the young palm's bulb (younger than 2 years). Later, the male opens a lateral perforation, where after 10 days the female arrives to copulate. In this process, the young oil palm bulb is

\footnotetext{
*Correspondence: adriana.saenz@javeriana.edu.co

Laboratory for Biological Control, Plant Biology and Productive System

Group, Department of Biology, School of Sciences, Pontificia Universidad Javeriana, Bogotá, Colombia
}

damaged, including the meristematic tissue causing the palm's death (Ahumada et al. 1995). Later on, the saprophylagous larvae feed on the rotting wood, especially in infested renewal palm lots. The life cycle has an average duration of 307.8 days (egg: 14.5 days; instar larvae: First instar larva: 24.4 days, Second instar larva: 41.6 days, Third instar larvae: 200.5 days; pupae: 26.8 days). Furthermore, $90 \%$ of this organism's life cycle is within the larval stages encompassing 267 days (Ahumada et al. 1995; Coto and Saunders 2004).

Strategus aloeus is a pest with economic impact; however its control has been limited to insecticide use and residue handling in renewal palm lots (Cipriano et al. 2010; Aldana et al. 2011). Therefore, entomopathogenic nematodes (EPN) have been considered as a potential control agent. Heterorhabditis and Steinernema EPN offer advantages of mutualistic association with bacteria

\section{Springer}


of the genera Xenorhabdus and Photorhabdus, respectively (Kaya and Gaugler 1993), high virulence, and rapid action to kill their host. The infective juvenile stage (IJ) does not feed, since it is morphologically and physiologically adapted to survive for long periods within the soil in the absence of its host. In addition, it is capable of parasitizing its host by entering through the mouth, anus, spiracles, cuticle and first generation heterorhabditid hermaphrodite (Shapiro Ilan et al. 2014). Palmas del Cesar is searching to establish S. aloeus biological control to reduce environmental pollution due to continued insecticide use, reduce costs, and loss of young palm plants. Therefore, we evaluated EPN isolated from the Colombian Andean region on S. aloeus third instar larvae under laboratory conditions.

\section{Methods}

Strategus aloeus larvae were collected in oil palm renewal lots in the department of Cesar in "Palmas del Cesar S.A Group" in Corregimiento de Minas, San Martín-Cesar Km. 113. Third instar larvae were used due to their availability in renewal lots in this plantation.

EPN species/strains were obtained from the Colombian Andean region from Centro Nacional de Investigaciones de Café (CENICAFE Agreement 182-2009, Table 1) and Pontificia Universidad Javeriana. All assays were performed under controlled conditions at $15{ }^{\circ} \mathrm{C}$ and $75 \%$ relative humidity in the Laboratory for Biological Control.

\section{Susceptibility evaluation}

Oil palm plantation soil $(89.5 \mathrm{~g})$ was placed into a plastic vial $(10.3 \mathrm{~cm} \times 8.5 \mathrm{~cm} \times 5.0 \mathrm{~cm})$ with one $S$. aloeus larvae and $160 \mathrm{IJs} / \mathrm{cm}^{2}$ resuspended in $3 \mathrm{ml} \mathrm{dH_{2 }} \mathrm{O}$ (Table 1). Untreated controls were identical to the treatments except that no IJs were added. Larvae mortality was registered every $24 \mathrm{~h}$ during 2 weeks, based on symptoms and corroborated by dissections, to verify nematode presence. Based on these results (highest mortality Table 1)

Table 1 Evaluated entomopathogenic nematode (EPNs) species/strains for the control of Strategus aloeus

\begin{tabular}{|c|c|c|}
\hline Species & Strain & Source \\
\hline Steinernema websteri & JCL006 & Chinchiná-CaldasCenicafe \\
\hline Steinernema feltiae & SCT125 & Scientia \\
\hline Steinernema sp3 & $\mathrm{JCL} 027$ & $\begin{array}{l}\text { Sasaima_Cundinamarca } \\
\text { Cenicafe }\end{array}$ \\
\hline Steinernema colombiense & SNI0198 & Quimbaya-Quindio Cenicafe \\
\hline Heterorhabditis bacteriophora & HASA702 & Riofrio_-Valle del Cauca \\
\hline Heterorhabditis bacteriophora & HNI0100 & Fresno_-Tolima Cenicafe \\
\hline Heterorhabditis indica & SL0708 & Alcaliá—Valle del Cauca \\
\hline
\end{tabular}

different IJs doses were assayed at $0,160,290,420,550$, $680,810 \mathrm{IJs} / \mathrm{cm}^{2}$ in $3 \mathrm{ml} \mathrm{dH_{2 }} \mathrm{O}$ suspension to select the best dose response (Grewal et al. 2005).

\section{Statistical analysis}

Susceptibility evaluation was performed with a completely randomized design (7 EPNs isolations $v s$. larval stage of the insect pest). Each treatment consisted of 20 experimental units and the experiment was repeated three times on different dates. For dose evaluation a completely randomized design was used (one EPN species/ strain vs. pest larval stage). Each treatment had 12 experimental units and the experiment was repeated three times on different dates.

All data were analyzed for normality (Shapiro-Wilk and Kolmogorov-Smirnov test) and homogeneity of variance (Levene test) with comparisons established by ANOVA. For significant differences between treatments an HSD Tukey test was performed. All analyses were carried out in SPSS-PC v.21 and Statistix 9.0, with a significance level of $p<0.05$.

\section{Results}

Strategus aloeus third instar larvae were susceptible to all EPNs species/strains evaluated $(\mathrm{F}=11.127, \mathrm{df}=7$, $24, \mathrm{p}=0.0054)$. Mortality was achieved between 3 and 14 days of treatment, with the latter hours presenting the greatest mortality rates. There was no mortality for controls. Steinernema sp3 JCL027 was the strain with highest mortality rate $(19.3 \pm 8 \%)$, followed by $H$. bacteriophora HNI0100 $(5.2 \pm 9 \%)$. The remaining treatments were between 1.75 and $5.26 \%$ (Fig. 1).

Symptoms of susceptibility in S. aloeus included red coloration patterns for individuals affected by Heterorhabditidae (Fig. 2a-c) and different browns for Steinernematidae (Fig. 2a, d). With the exception of the posterior segment a sagging body was observed, due to substrate accumulation, with lack of putrefying smell. In addition, total liquefaction of internal tissues was evidenced, as well as presence of nematode developing stages: females, males, hermaphrodites, and juveniles. Furthermore, we observed intact fat bodies in some dead larvae.

Steinernema sp3 JCL027 was selected for dose evaluation, since it presented the highest mortality rate for S. aloeus larvae in their third instar (Fig. 1). Significant differences were observed for $680 \mathrm{IJs} / \mathrm{cm}^{2}(44 \pm 5 \%$, $\mathrm{p}=0.001)$, followed by $810 \mathrm{IJs} / \mathrm{cm}^{2}(22 \pm 5 \%)$ (Fig. 3).

\section{Discussion}

Species and their different instar larvae within the Scarabaeidae and Melolonthidae families frequently present highly variable susceptibilities to EPNs action (Grewal 


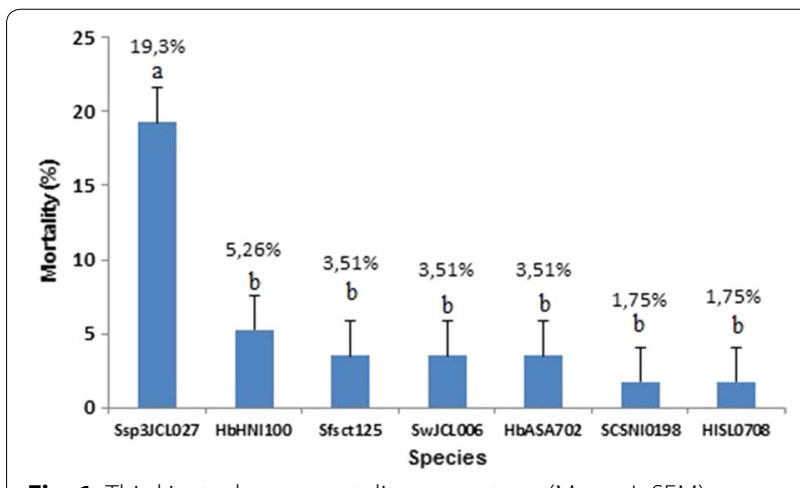

Fig. 1 Third instar larvae mortality percentage (Mean \pm SEM). Strategus aloeus third instar larvae mortality percentage treated with Ssp3JCL027: Steinernema sp3 JCL027; HbHNI0100: H. bacteriophora HNI0100; Sfsct125: S. feltiae SCT125; Sw JCL006: S. websteri JCL006; HbASA702: H. bacteriophora ASA702; SC SNI0198: S. colombiense SNI0198; HI SL0708: Heterorhabditis indica SL0708. Bars indicate standard deviation. Letters above bar indicate significant differences (ANOVA with Tukey post hoc test $p<0.05$ )

et al. 2005; Koppenhöfer et al. 2006; Khatri-Chhetri et al. 2011). Therefore, it is critical to evaluate species/strain EPNs dose to determine which generates the greatest pathogenicity. All evaluated S. aloeus isolations demonstrated important variabilities, with mortality rates inferior to those reported for other instar larvae species affected by Steinernematidae and Heterorhabditidae.

In a report presented by Sánchez-Saavedra et al. (2012), employing a $2500 \mathrm{IJs} / \mathrm{ml}$ (19.8 IJs/larvae) $H$. indica dose on different Phyllophaga spp. (Coleoptera:
Melolonthidae), third instar larvae mortality was $46 \%$. Likewise, Khatri-Chhetri et al. (2011), assessed the pathogenic capability of seven EPN on Holotrichia longipennis (Coleoptera: Scarabaeidae) third instar larvae using a concentration of $1000 \mathrm{IJs} /$ larva $\left(50 \mathrm{IJ} / \mathrm{cm}^{2}\right)$ with mortalities ranging between 35.6 and $72.8 \%$. Furthermore, Quintero-Marin et al. (2006) evaluated H. bacteriophora HNI0100, Steinernema sp. SNI0198, and Heterorhabditis spp. pathogenicity and infectivity.

Centro International de Agricultura Tropical (CIAT) conducted a study where doses of 7000 and 13,000 IJ/larvae (7000 and 13,000 IJs/ml) with both Steinernema and Heterorhabditis as a biological insecticide in Phyllophaga menetriesi (Coleoptera: Melolonthidae) third instar pest management was tested. Their results evidenced a greater infectivity for Steinernema genus ( $>80 \%)$ in comparison with Heterorhabditis (52.9 \%). Melo et al. (2007) evaluated S. feltiae and H. bacteriophora (HNI) (10,000 IJs/ ml-10,000 IJs/larvae) pathogenicity on P. menetriesi and Anomala inconstans (Coleoptera: Melolonthidae) third instar larvae. Their results demonstrated greater mortalities for $H$. bacteriophora HNI.

Contrary to that reported in the literature, Steinernema sp3 JCL027 had a greater susceptibility compared with Heterorhabditis efficacy against S. aloeus third instar larvae. We suggest Steinernema sp3 JCL027 IJs were able to overcome the host's barriers and physiological mechanisms to evade an immune response or digestive tract acidity, permitting the subsequent nematodebacteria infective cycle development (An et al. 2012; Demir et al. 2014). Taking into account Scarabaeidae
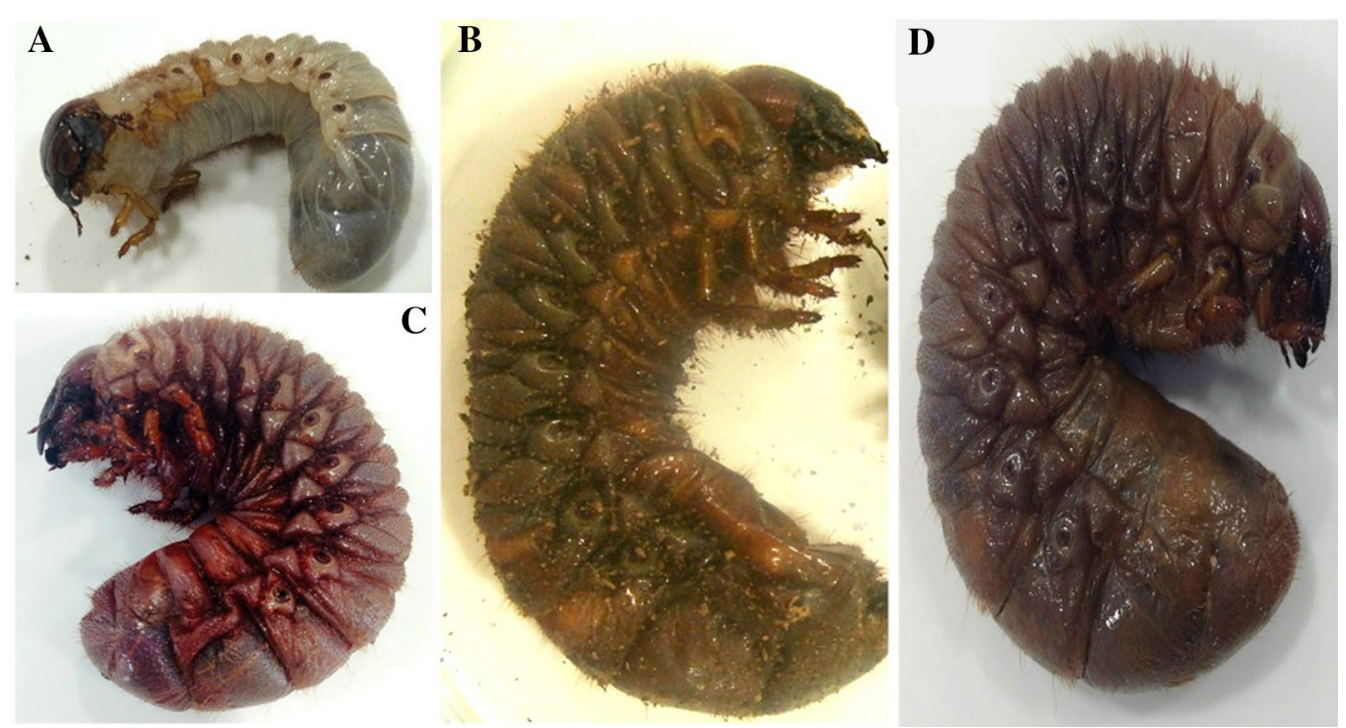

Fig. 2 Strategus aloeus third instar larvae coloration in control and entomopathogenic nematode treatments: a Healthy larvae. b Infected larvae with Heterorhabditis indica SL0708. c Infected larvae with H. bacteriophora ASA702. d Infected larvae with Steinernema sp3 JCL027 


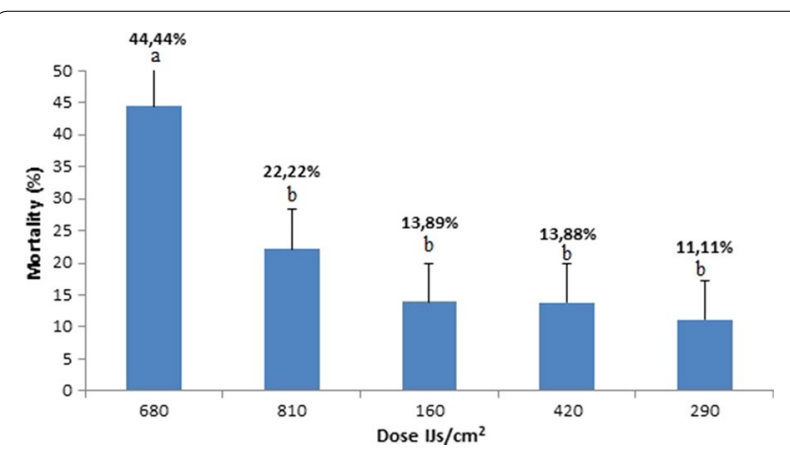

Fig. 3 Mortality percentage. Strategus aloeus third instar larvae mortality percentage (Mean \pm SEM) treated with different doses of Steinernema sp3 JCL027. Letters above bar indicate significant differences (ANOVA with Tukey post hoc test $p<0.05$ )

and Melolonthidae immune response defense, in particular during their third instar (Griffin et al. 2005), we expected S. aloeus would be more susceptible to Heterorhabditis than Steinernematids based on certain advantages (Khatri-Chhetri et al. 2011; Vashisth et al. 2013). As a case in point, Heterorhabditis IJs can enter its host through intersegmental membranes of the cuticle. Moreover, it exhibits a foraging behavior depending on the species to be controlled. However, Scarabaeidae and Melolonthidae third instar larvae present a thicker cuticle (Rodríguez et al. 2009), possibly impeding intersegmental membrane access. Therefore, this event may account for lower S. aloeus mortality rate when using Heterorhabditis as a pest control.

Under controlled laboratory conditions, during our nematode species/strain screening, S. aloeus mortality rate did not exceed $20 \%$ compared with mortality rates of 46 to $85 \%$ for other reports in the literature (Grewal et al. 2005; Quintero-Marin et al. 2006; Melo et al. 2007). We suggest our result might be due $S$. aloeus constant grooming behavior by scrubbing its raster with the aid of its legs and mouth parts. In addition, it is capable of rapid mandible movement, evasive behavior, and constant defecation. Probably, S. aloeus significantly reduced its susceptibility to each of the EPNs isolates it was exposed to. Another factor affecting susceptibility variation could be EPNs-host specificity. Larvae could have been partially resistant to EPNs' infection, due to S. aloeus morphology, physiological defense mechanisms or IJs symbiotic bacteria. This latter one could have possibly not been virulent for this insect pest, as it has been reported for other Lepidoptera (Bisch et al. 2015).

It was not unexpected that an increased Steinernema sp3. JCL027 concentration did not always present a concomitant increase in $S$. aloeus death, as was the case for the $680 \mathrm{IJs} / \mathrm{cm}^{2}$ and $810 \mathrm{IJs} / \mathrm{cm}^{2}$ doses. Quintero-Marin et al. (2006) evaluated the pathogenicity and infectivity of three EPNs, finding similar results. In their study Steinernema spp. SNI 0198 and H. bacteriophora HNI 0100 presented a greater infectivity (\% penetration) at a lower dose (7000 IJs), while the 13,000 dose was significantly lower. Likewise they found in their first pathogenicity reading Steinernema sp. SNI 0198 and Heterorhabditis spp. CIAT also presented greater mortalities at the lower does (7000 IJs/ml compared with the 13,000 dose). According to Kaya and Koppenhöfer (1996), this can be attributed to IJs intraspecific competition to enter the host at a given concentration. It is important to keep in mind that exposing a host to specific numbers of nematodes does not imply that all of them can enter the host. Even if they are capable of doing so, they still have to encounter a number of barriers until reaching the hemocoel. Furthermore, penetration does not necessarily imply a subsequent mortality (Demir et al. 2014; Bisch et al. 2015).

Observed symptoms in S. aloeus third instar larvae after performed infections agree with what has been described for other larvae of the Scarabaeidae and Melolonthidae families: larvae stop eating; they decrease their motility, and change in color (Rodríguez et al. 2009; Sánchez-Saavedra et al. 2012). However, when we performed dissections to validate mortality not all were found to contain liquefied tissues. The life cycle of the infective juvenile requires the nematode to penetrate the host, and then enter into the hemocoel. The juvenile can then release their symbiotic bacteria from their intestines into the host's hemocoel. The bacteria can subsequently proliferate in the host causing septicemia, permitting the nematode to develop its life cycle. (An et al. 2012; Bisch et al. 2015). Collectively, reports describe some bacteria are capable of eliciting a pathogenic reaction, therefore the host's immune response acts by encapsulation, phagocytosis, among others. In this manner the nematode life cycle does not develop. Even though these events have been characterized we did not evaluate them, therefore we cannot assume they are associated.

\section{Conclusion}

To achieve even higher S. aloeus larvae mortality percentages than was obtained in the "Palmas del Cesar" management program using the tested EPNs as biological control agents, it may be pertinent to evaluate other entomopathogenic fungi including Beauveria bassiana and Metarhizium anisopliae naturally affecting the third instar larvae, as well as Serratia spp. an entomopathogenic bacteria. In addition, synergistic associations may occur among combinations of different entomopathogens. Also, it would be worthwhile to evaluate virulent capability of other EPNs (individual or combined 
applications) adapted for these larvae, possibly present in oil palm lots and their symbiotic bacteria for all instar larvae and adult S. aloeus.

\section{Authors' contributions}

AS-A conceived and designed the study, raised funds, organized the research and contributed to the writing of the final manuscript. AG performed experiments and analyzed the data. Both authors read and approved the final manuscript.

\section{Acknowledgements}

Authors thank Palmas del Cesar plantation for obtaining and shipping S. aloeus for all assays performed, particularly Viviana Dueñas and Yudi Liliana Cadenas. In addition we are grateful with Mr. Willi Girona for transporting samples to the Laboratory for Biological Control. The results here presented correspond to the Project: Pest and disease control of important iberoamerican crops by natural enemy implementation, ID 4169. Authors thank Pontificia Universidad Javeriana for financing this publication.

\section{Competing interests}

Authors declare that there are no conflicts of interest related to the results obtained in this study.

Received: 23 July 2015 Accepted: 7 October 2015

Published online: 16 October 2015

\section{References}

Ahumada FM, Calvache H, Cruz MA, Luque JF (1995) Strategus aloeus L. (Coleoptera: Scarabaeidae): Biología y comportamiento en Puerto Wilches (Santander). Palmas (Colombia) 16(3):9-16

Aldana R, Aldana J, Calvache H, Franco P (2005) Plagas de la palma de aceite en Colombia. Centro de investigaciones en palma de aceite Cenipalma, p 102

Aldana RC, Aldana JA, Moya OM (2011) Manejo del picudo Rhynchophorus palmarum L. (Coleoptera: Curculionidae) —Instituto colombiano agropecuario (ICA) http://bit.ly/1cmZVJR. Retrieved Diciembre 102013

An R, Voss M, Jagdale GB, Grewal PS (2012) Differences in immune defense evasion of selected inbred lines of Heterorhabditis bacteriophora in two white grub species. Insect. 3:378-389

Bisch G, Page S, McMullen, Stock P, Duvic B, Givaudan A, Gaudriault S (2015) XenorhabdusbovieniiCSO3, the bacterial symbiont of the entomopathogenic nematode Steinernema weiseri, is a non-virulent strain against lepidopteran insects. J Invertebr Pathol 124:15-22

Cipriano A, Moya OM, Rincón AH, Aldana RC, Gomes H (2010) Dinámica de reproducción de Strategus aloeus bajo diferentes métodos de erradicación y daño causado en la nueva siembra. Ceniavances 166:1-4
Coto D, Saunders JL (2004) Orden Coleoptera. In: Coto D, Saunders JL (eds) Insectos de plagas de cultivos perennes con énfasis en frutales en América Central. Centro agronómico Tropical de investigación y enseñanza, Turrialba, p 137

Demir S, Karagoz M, Hazir S, Kaya H (2014) Evaluation of entomopathogenic nematodes and their combined application against Curculio elephas and Polyphyllafullo larvae. J Pest Sci 88(1):163-170

Grewal PS, Koppenhöfer MA, Choo HY (2005) Lawn, Turfgrass and pasture applications. In: Grewal PS, Ehlers RU, Shapiro DI (eds) Nematodes as biocontrol agents. CABI publishing, USA, pp 115-146

Griffin CT, Boemare NE, Lewis EE (2005) Biology and behaviour. In: Grewal PS, Ehlers RU, Shapiro DI (eds) Nematodes as biocontrol agents. CABI publishing, USA, pp 47-64

Kaya HK, Gaugler R (1993) Entomopathogenic nematodes. Annu Rev Entomol 38:181-206

Kaya HK, Koppenhöfer AM (1996) Effects of microbial and other antagonistic organism and competition on entomopathogenic nematodes. Biocontrol Sci Tech 6:357-371

Khatri-Chhetri HB, Timsina GP, Manandhar HK, Moens M (2011) Potential of Nepalese entomopathogenic nematodes as biocontrol agents against Holotrichialongipennis Blanch. (Coleoptera: Scarabaeidae). J Pest Sci 84:457-469

Koppenhöfer AM, Grewal PS, Fuzy EM (2006) Virulence of the entomopathogenic nematodes Heterorhabditisbacteriophora, Heterorhabditiszealandica, and Steinernema scarabaei against five white grub species (Coleoptera: Scarabaeidae) of economic importance in turfgrass in North America. Biol Control 38:397-404

Melo EL, Ortega CA, Gaigl A (2007) Efecto de nematodos sobre larvas de Phyllophagamenetriesi y Anomalainconstans (Coleoptera: Melolonthidae). Revista Colombiana de Entomología 33(1):21-22

Quintero-Marin P, Caicedo AM, Montoya-Lerma M, Gaigl A (2006) Evaluation of three native entomopathogenic nematodes (Rhabditidae) against third instar larvae of Phyllophagamenetriesi (Coleoptera: Scarabaeidae). Int J Trop Insect Sci 26(4):233-238

Rodríguez D, Torres M, Uribe L, Flores L (2009) Susceptibilidad de los estadios L2 y L3 de Phyllophagaelenans a una cepa nativa de Heterorhabditissp. en condiciones de invernadero. Agronomía Costarricence 33(2):171-182

Sánchez-Saavedra MG, Cortez-Madrigal H, Cristobal-Acevedo H (2012) Infectividad de Heterorhabditis indica (Rhabditida: Heterorhabditidae) en adultos y larvas de gallina ciega (Coleoptera: Melolonthidae). Revista Chapingo Serie Horticultura 18(3):383-394

Shapiro Ilan D, Han R, Xuehong Q (2014) Production of entomopathogenic nematodes. In: Morales RJ, Ramos G, Shapiro D (eds) Mass production of beneficial organisms: invertebrates and entomopathogens. Academic Press, p 321

Torres-Carrasco RA, Girón-Amaya EG, Rincón-Vargas FM, Ruiz-Delgado RJ (2013) Minianuario estadístico 2013: Principales cifras de la agroindustria de la palma de aceite en Colombia-Fedepalma. http://bit.ly/1 cwttlg. Retrieved 9 Dec 2013

Vashisth S, Chandel YS, Sharma PK (2013) Entomopathogenic nematodes-a review. Agric Rev 34(3):163-175

\section{Submit your manuscript to a SpringerOpen ${ }^{\circ}$ journal and benefit from:}

Convenient online submission

- Rigorous peer review

- Immediate publication on acceptance

- Open access: articles freely available online

- High visibility within the field

- Retaining the copyright to your article

Submit your next manuscript at $>$ springeropen.com 